No. Issue: 15 | Communication |pp. 107-112

\title{
Color-ornamental Plants Cultivation for Metal Waste Reduction on Mining Sites and Their Biorecovery of Metals
}

\author{
Rizky Arief Shobirin ${ }^{1}$ *, Ahsin Daroini ${ }^{2}$, and Edy Suwasono ${ }^{3}$ \\ 1 Department of Chemistry, Faculty of Agriculture, Islamic University of Kadiri; \\ 2 Department of Agribusiness, Faculty of Agriculture, Islamic University of Kadiri; \\ 3 Department of Management, Faculty of Economics, Islamic University of Kadiri; \\ * Correspondence: rizkyariefs@ uniska-kediri.ac.id; rashobirin@gmail.com
}

Received: 16 August 2019; Accepted: 25 August 2019; Published: 29 September 2019

\begin{abstract}
Metals, Minerals and Rock as minerals, are important aspects in the economic and social development of a country. However, due to the lack of communication between the private sector as a miner and the government as a supervisory party, there has been a lot of illegal mining occurring and no effort to revise the environment so that it has an impact on people's welfare and environmental pollution that is increasingly high. So as to reduce the level of environmental pollution that is currently needed there is the processing of mining waste. The metal will form complex bonds of coordination with ligands and form compounds of a certain color. By knowing the nature of these plants, the selection of plants that have a tendency to bind metal ions can be complexly coordinated to reduce the waste of metal ions generated from mining processing activities or on mining sites.
\end{abstract}

Keywords: color ornamental plants; biorecovery; mining site; metal waste; waste reduction

\section{Introduction}

Metals, Minerals and Rock as minerals, are important aspects in the economic and social development of a country. The mining material is currently widely applied as a starting material in the manufacture of application materials such as electronic equipment, to jewelry. However, however, the existence of these mining items has limited the amount of resources available in a place [1]. Some problems that often occur today are illegal mining and weak government control in the continuation of mining activities. The local government also does not have a very good insight related to mining activities which actually gives a lot of adverse impacts on the environment, as well as the lack of weak utilization of mineral resources in certain areas. These mineral resources should be one of the sources of income from the economic sector to provide welfare to the community. However, due to the lack of communication between the private sector as a miner and the government as a supervisory party, there has been a lot of illegal mining occurring and no effort to revise the environment so that it has an impact on people's welfare and environmental pollution that is increasingly high. So as to reduce the level of environmental pollution that is currently needed there is the processing of mining waste.

\section{Coordination Covalent Bonding between Metals and Color-ornamental Plants}

The metal will form complex bonds of coordination with ligands and form compounds of a certain color. This also applies to plants that have large molecular weight ligands, for example in plants shown in Figure 1. Metal ions such as iron $(\mathrm{Fe})$, zinc $(\mathrm{Zn})$, manganese $(\mathrm{Mn})$ and copper $(\mathrm{Cu})$, which in Mining sites often become waste, instead they play an important role for healthy plant growth, which is needed for the structural and catalytic role in proteins involved in metabolism and development. However, excess free metal ions are toxic to cells because the generation of reactive oxygen species or through the transfer of other metal ions from sites in 
metalloproteins makes them function[2-4]. Therefore plants have a mechanism for metal homeostasis that allows the absorption and distribution of metals to tissues while keeping metals in cells or subcellular compartments below the level that causes toxic symptoms $[2,4,5]$.

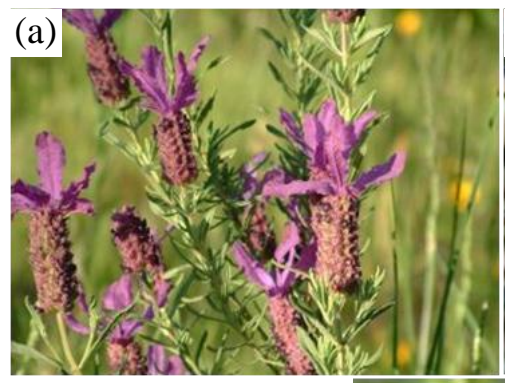

(d)
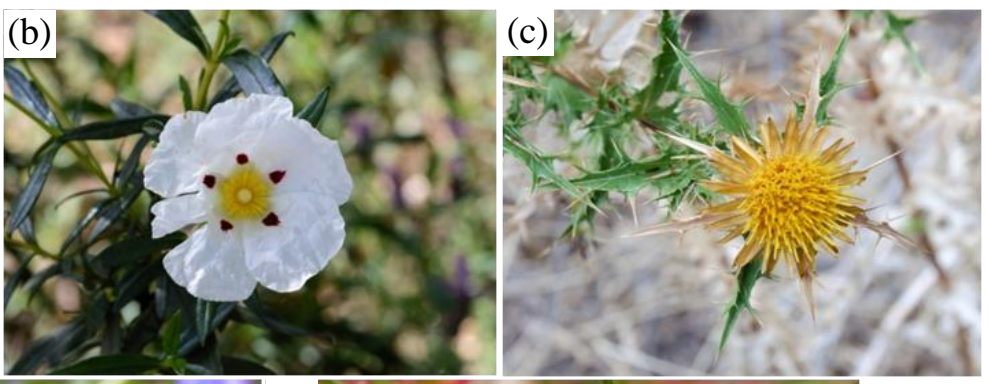

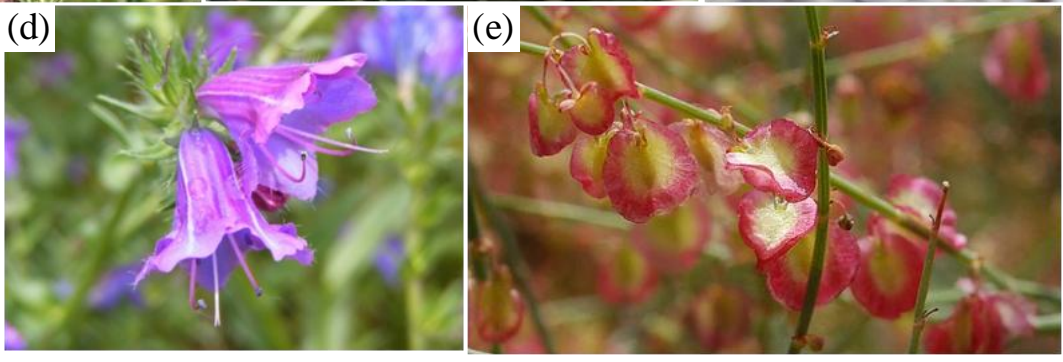

Fig. 1. Ornamental plants used in mining waste treatment and metal biorecovery, (a) Lavandula luisieri [23], (b) Cistus ladanifer [24], (c) Carlina corymbosa [25], (d) Echium plantagineum [26] , and (e) Rumex induratus [27], courtesy on Wikipedia; Mediterranean Botanical Garden Society; and Ideal Waste.

Ornamental plants, which have a certain color, have their own mechanism to bind metal ions to bind to their cells as ligands and form complex compounds. As explained in Figure 2 and Figure 3, metal ions that enter the root will undergo transformation spread in all parts of plant cells, such as roots, stems, leaves, to flowers. The attachment also certainly has the strength of different molecules attraction, and of course produces different physical shapes such as color [28]. By knowing the nature of these plants, the selection of plants that have a tendency to bind metal ions can be complexly coordinated to reduce the waste of metal ions generated from mining processing activities or on mining sites. In the referenced research article, the selection of plants used to reduce the abundance of metal waste by using ornamental plants that aesthetically have a certain color dominance, and of course later will be discussed further for the attachment of a metal ion from the waste with ornamental plants that are made of metal-trap plants.

\section{Methodology Review}

Eighty-five plant samples were collected from different sampling locations from the mining area. For each type of plant, in this case the plants used include Lavandula luisierra, Erica australis, Rumex induratus, Corrigiola telephypholia, Agrostis castellana, Eritrae pulcheria, Daphne gnidium, Carlina corymbosa, Cistus ladanifer, Corrigiola telephypholia, Agrostis castellana, Eritrae pulcheria, Daphne gnidium, Carlina corymbosa, Cistus ladanifer, Corrigiola telephypholia, Agrostis castellana, Eritrea and Genista hirsutus, five plant samples were collected from one sampling location and mixed together. The roots, stems, leaves and flowers of these plant species are separated. The roots are washed with water and rinsed with $\mathrm{HCl}$ solution followed by several rinses with DO water. The shoots (stems, leaves, and flowers) of plant species are washed with water followed by several rinses with DO water to remove all particulate matter attached to the stems, leaves, and flowers (buds). The cleaned and washed plant material is carried out, ground in a ball mill until homogeneous, and made into pellets for neutron activation analysis, following the standard procedure. Subsequently the sample was analyzed for mineralogy and chemical elements [22]. 


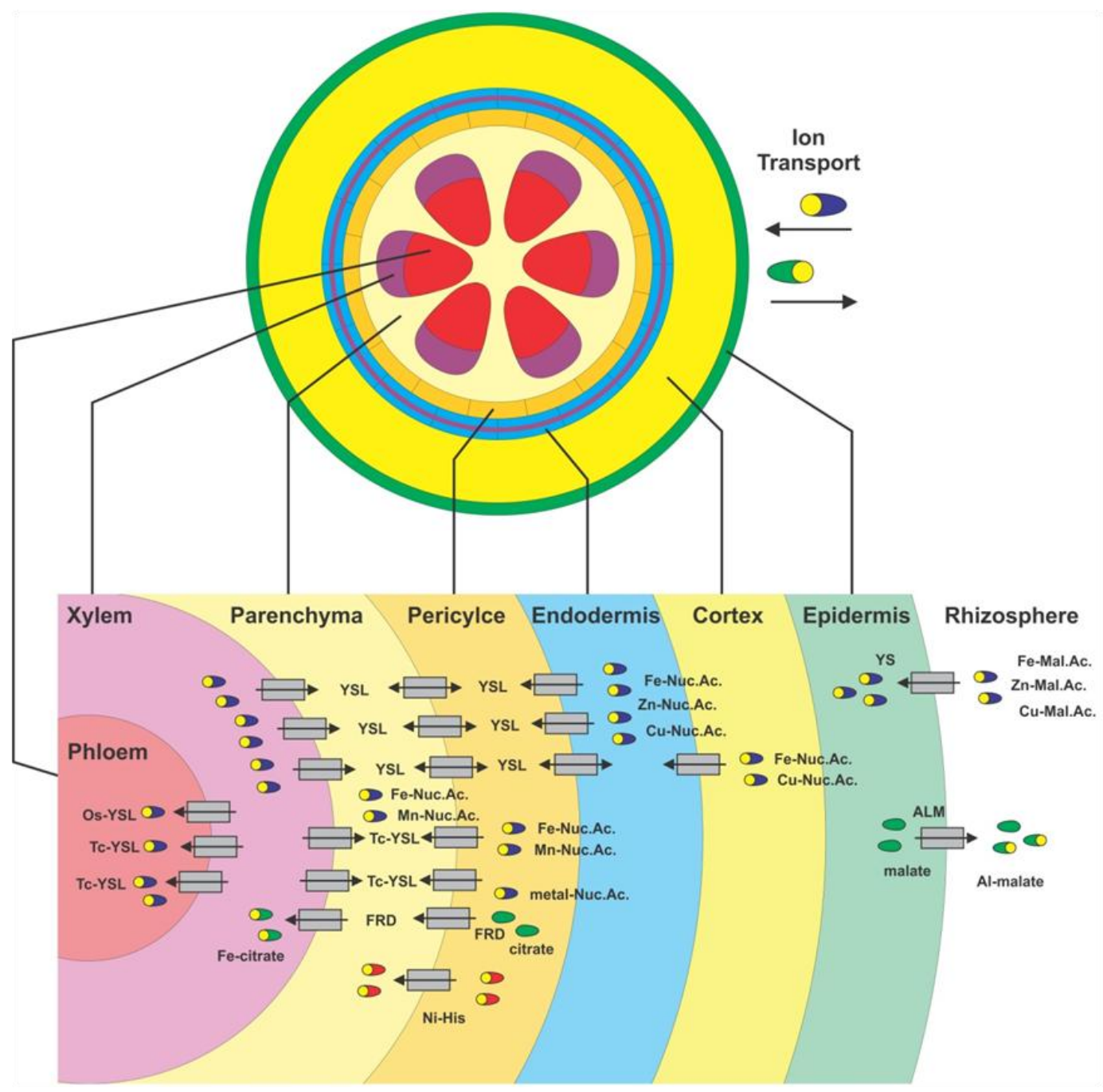

Fig. 2. Localization and distribution of metal ions in stem cells, according to the references [2-3,56,8-11,14-16,19-21]

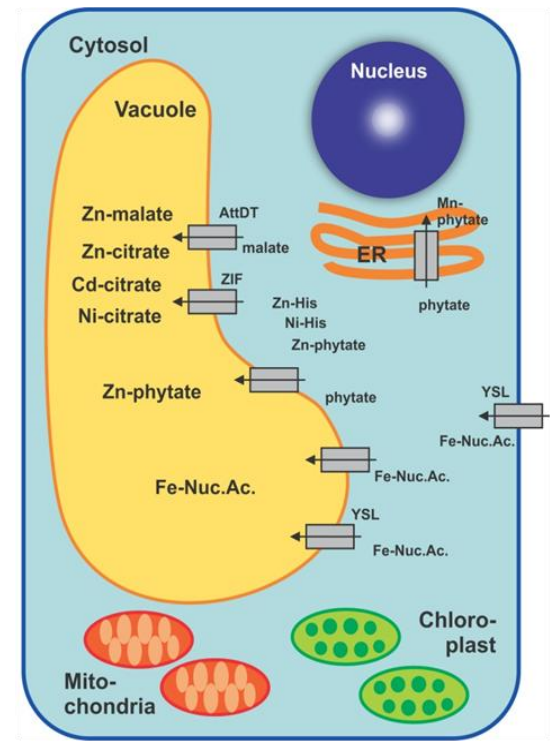

Fig. 3. Localization and distribution of metal ions in plant cells and forming complex bonds, adapted from the references [2,4-6,9-13,16-18]. 


\section{Discussion}

From the results of the analysis shown in table 1, a list of the metal elements captured in significant amounts and greatly reducing pollution is indicated by columns $\mathrm{As}, \mathrm{Cr}, \mathrm{Fe}$, and $\mathrm{Zn}$. From the results of the planting, Cd metal is not much attached to ornamental plants grown in any mining site area. However, one of the most toxic metals absorbed in plants is the As metal, which is significantly absorbed by plant species Erica andavalensis and Erica australis and found in the flower section. The accumulation of other recorded metal wastes, Sb, is almost similar to the As metal absorption trend, which is highest in plant species Erica andavalensis and Erica australis and found in the flower section.

Table 1. Concentrations of absorbed metals in the plant species section [22], quoted from Springer-verlag (2011).

\begin{tabular}{|c|c|c|c|c|c|c|c|c|}
\hline \multirow{2}{*}{ Plants Species (Plant's parts) } & \multicolumn{8}{|c|}{ Concentration Range of Trace Elements (ppm) } \\
\hline & As & Co & $\mathbf{C r}$ & Cs & $\mathbf{F e}$ & $\mathbf{S b}$ & Se & $\mathbf{Z n}$ \\
\hline Lavandula luisierra (leaves) & $5-10$ & \multirow{3}{*}{$<1$} & 10-15 & \multirow{10}{*}{$<0.01$} & $500-700$ & $1-2$ & 3-5 & $300-400$ \\
\hline Erica australis (Leaves) & $25-30$ & & 8-10 & & $\begin{array}{c}1,000- \\
1,200\end{array}$ & 3-5 & $<1$ & $37-42$ \\
\hline Rumex induratus (Stem) & $<5$ & & $8-10$ & & $300-400$ & $<1$ & $10-14$ & $33-35$ \\
\hline Corrigiola telephypholia (Leaves) & $10-20$ & $1-2$ & $5-8$ & & $800-1,000$ & $3-4$ & \multirow{2}{*}{$1-3$} & $220-250$ \\
\hline Agrostis castellana (Upper Roots) & $5-10$ & \multirow{2}{*}{$<1$} & $3-5$ & & $250-350$ & $\sim 1$ & & $25-30$ \\
\hline Eritrae pulcheria (Upper roots) & $10-15$ & & $5-8$ & & $500-700$ & $1-3$ & $4-6$ & $37-42$ \\
\hline Daphne gnidium (Leaves) & $<5$ & \multirow{2}{*}{$<1$} & $8-10$ & & 250 & $<1$ & $15-20$ & 90-110 \\
\hline Carlina corymbosa (Leaves) & \multirow{7}{*}{$5-10$} & & $10-12$ & & $500-700$ & $1-2$ & $5-10$ & $\sim 40$ \\
\hline Cistus ladanifer (Leaves) & & $2-3$ & 8-10 & & $250-350$ & $<1$ & 13-15 & $100-200$ \\
\hline Erica australis (Leaves) & & $1-2$ & $5-10$ & & $400-500$ & $1-2$ & $<1$ & $70-90$ \\
\hline Ulex eriocladus (Upper roots) & & \multirow{2}{*}{$<1$} & \multirow{2}{*}{ 8-10 } & \multirow{2}{*}{$<1$} & $300-400$ & \multirow{2}{*}{$<1$} & $3-5$ & $30-40$ \\
\hline Lavandula luisierra (Leaves) & & & & & $250-350$ & & $\sim 5$ & 90-110 \\
\hline Echium plantagium (Leaves) & & \multirow{2}{*}{$<1$} & $10-15$ & 0.12 & $400-500$ & $2-3$ & $3-5$ & $70-90$ \\
\hline Gramina (Upper roots) & & & $10-13$ & $<0.1$ & $300-400$ & $1-2$ & $1-3$ & $40-60$ \\
\hline Erica australis (Flowers) & $35-40$ & $3-5$ & $5-10$ & $<0.2$ & $800-1,000$ & $2-4$ & $<0.5$ & $300-400$ \\
\hline Erica andevalensis (Flowers) & $40-50$ & $2-3$ & \multirow[t]{2}{*}{ 8-10 } & $1-2$ & $\begin{array}{c}1,000- \\
1,200\end{array}$ & $5-7$ & $<1$ & 200-300 \\
\hline Genista hirsutus (Upper roots) & $5-10$ & $<1$ & & $<0.1$ & $300-400$ & $<1$ & $<0.5$ & $33-35$ \\
\hline
\end{tabular}

When viewed as a whole, plant species Erica andavalensis and Erica australis are plants that absorb the most metal waste ( $\mathrm{Fe}, \mathrm{As}, \mathrm{Cr}, \mathrm{Cs}, \mathrm{Zn}$, and $\mathrm{Sb}$ ) from the mining site, although for $\mathrm{Se}$ it is lower. When viewed from the physical appearance and growth, this plant species is a plant that has thick purple flowers, so it is not surprising that a lot of metal content is bound to many parts of the plant $[2,5,7]$. When viewed more closely related to its growth, this plant is a plant that is very tolerant to be grown or cultivated anywhere, so this plant is very applicable to be used as metal-trap plants at the mine site which is being hit by a waste treatment $[7,11,16-15]$. This plant also has a high level of photostability compared to the others, so that when it absorbs a lot of metal waste it does not cause damage to the plant [2,5,16-19]. However, these conditions will actually further emphasize the color of the flowers of these Erica species plants so that they can also increase the power and selling prices of these plants [22]. Therefore, tracing back the results of research conducted and the potential of plant species Erica andavalensis and Erica australis, it can be concluded that these plants can be cultivated in Indonesia to reduce mining waste, protect the environment from pollution, and increase plant competitiveness in the field of cultivation, so that mining metal biorecovery will not be wasted and can be utilized and further processed to be applied in the industrial field, especially the electronic material industry or heavy equipment. 


\section{Conclusions}

Based on the objective, it can be concluded that ornamental plants have their own mechanism to bind metal ions to bind to their cells as ligands and form complex compounds, as identified physically by its certain color. The selection of plants that have a tendency to bind metal ions can be complexly coordinated to reduce the waste of metal ions generated from mining processing activities or on mining sites. When viewed from the physical appearance and growth, ornament plant species have several colors; therefore it is not surprising that a lot of metal content is bound to many parts of the plant. If viewed more closely related to its growth, these ornamental plants is highly adaptable to be grown or cultivated anywhere, so this plant is very applicable to be used as metal-trap plants for mining waste treatment. On forward, it is potentially prospective for mining waste reduction and environment protection from pollution.

\section{Acknowledgement}

The authors would like to contribute through this paper for sight open the horizons of people and government for development of sustainable environmental management system by natural ornamental plants in order to reduce environmental hazards, risks, and pollutions, especially on mining sites. No authors are in conflict of interest.

\section{References}

1. Afiatin Chattopadhyay, S., Chattopadhyay, D. 2013. Fossil Energy Selected Entries from the Encyclopedia of Sustainability Science and Technology, Springer Science+Business Media, Llc., New York, Chapter 12 : Mining Industries and Their Sustainable Management, pp. 443-476.

2. Haydon, M.J., Cobbett, C.S. 2007. Transporters of Ligands for Essential Metal Ions in Plants, New Phytologist, 174, pp. 499-506.

3. Becher, M., Talke, I.N., Krall, L., Kramer, U. 2004. Cross-Species Microarray Transcript Profiling Reveals High Constitutive Expression of Metal Homeostasis Genes in Shoots of the Zinc Hyperaccumulator Arabidopsis halleri. Plant Journal, 37, pp. 251-268.

4. Cobbett C, Goldsbrough P. 2002. Phytochelatins and Metallothioneins: Roles in Heavy Metal Detoxification and Homeostasis. Annual Review of Plant Biology, 123, pp. 825-832.

5. Curie, C., Briat, J.F. 2003. Iron Transport and Signaling in Plants. Annual Review of Plant Biology, 54, pp. 183-206.

6. Curie, C., Panaviene, Z., Loulergue, C., Dellaporta, S.L., Briat, J.F., Walker, E.L. 2001. Maize Yellow Stripe1 Encodes a Membrane Protein Directly Involved in Fe(III) Uptake. Nature, 409, pp. 346-349.

7. Delhaize, E. 1996. A Metal-Accumulator Mutant of Arabidopsis thaliana. Plant Physiology, 111, pp. 849-855.

8. DiDonato, R.J., Roberts, L.A., Sanderson, T., Eisley, R.B., Walker, E.L. 2004. Arabidopsis Yellow Stripe-Like2 (YSL2): a Metal-Regulated Gene Encoding a Plasma Membrane Transporter of Nicotianamine-Metal Complexes. Plant Journal, 39, pp. 403-414.

9. Douchkov, D., Gryczka, C., Stephan, U.W., Hell, R., Bäumlein, H. 2005. Ectopic Expression of Nicotianamine Synthase Genes Results in Improved Iron Accumulation and Increased Nickel Tolerance in Transgenic Tobacco. Plant, Cell \& Environment, 28, pp. 365-374.

10. Gendre, D., Czernic, P., Conéjéro, G., Pianelli, K., Briat, J-F., Lebrun, M., Mari, S. 2006. TcYSL3, a Member of the YSL Gene Family from the Hyperaccumulator Thlaspi 
Caerulescens, Encodes a Nicotianamine-Ni/Fe Transporter. Plant Journal, 49, pp. 115.

11. Grotz, N., Guerinot, M.L. 2006. Molecular Aspects of $\mathbf{C u}, \mathbf{F e}$ and $\mathrm{Zn}$ Homeostasis in Plants. Biochimica et Biophysica Acta-Molecular Cell Research, 1763, pp. 595-608.

12. Haydon, M.J., Cobbett, C.S. 2007. A Novel Major Facilitator Superfamily Protein at the Tonoplast Influences $\mathrm{Zn}$ Tolerance and Accumulation in Arabidopsis thaliana. Plant Physiology. DOI: 10.1104/pp.106.092015.

13. Ingle, R.A., Mugford, S.T., Rees, J.D., Campbell, M.M., Smith, J.A.C. 2005. Constitutively High Expression of the Histidine Biosynthetic Pathway Contributes to Nickel Tolerance in Hyperaccumulator Plants. Plant Cell, 17, pp. 2089-2106.

14. Kerkeb, L., Kramer, U. 2003. The Role of Free Histidine in Xylem Loading Of Nickel in Alyssum lesbiacum and Brassica juncea. Plant Physiology, 131, pp. 716-724.

15. Koike, S., Inoue, H., Mizuno, D., Takahashi, M., Nakanishi, H., Mori, S., Nishizawa, N.K. 2004. OsYSL2 is a Rice Metal-Nicotianamine Transporter that is Regulated by Iron and Expressed in the Phloem. Plant Journal, 39, pp. 415-424.

16. Kramer, U., Pickering, I.J., Prince, R.C., Raskin, I., Salt, D.E. 2000. Subcellular Localization and Speciation of Nickel in Hyperaccumulator and Non-Accumulator Thlaspi Species. Plant Physiology, 122, pp. 1343-1354.

17. Kupper, H., Mijovilovich, A., Meyer-Klaucke, W., Kroneck, P.M.H. 2004. Tissue- and Age-Dependent Differences in the Complexation of Cadmium and Zinc in the Cadmium/Zinc Hyperaccumulator Thlaspi Caerulescens (Ganges Ecotype) Revealed by X-Ray Absorption Spectroscopy. Plant Physiology 134, pp. 748-757.

18. Ma, J.F., Ueno, D., Zhao, F-J., McGrath, S.P. 2005. Subcellular Localisation of Cd and $\mathrm{Zn}$ in the Leaves of a Cd-Hyperaccumulating Ecotype of Thlaspi caerulescens. Planta, 220, pp. 731-736.

19. Sasaki, T., Yamamoto, Y., Ezaki, B., Katsuhara, M., Ahn, S.J., Ryan, P.R., Delhaize, E., Matsumoto, H. 2004. A Wheat Gene Encoding an Aluminum-Activated Malate Transporter. Plant Journal, 37, pp. 645-653.

20. Talke, I.N., Hanikenne, M., Kramer, U. 2006. Zinc-Dependent Global Transcriptional Control, Transcriptional Deregulation, and Higher Gene Copy Number for Genes in Metal Homeostasis of the Hyperaccumulator Arabidopsis halleri. Plant Physiology, 142, pp. 148-167.

21. Yen, M-R., Tseng, Y-H., Saier, M.H. Jr. 2001. Maize Yellow Stripe1, an IronPhytosiderophore Uptake Transporter, is a Member of the Oligopeptide Transporter (OPT) Family. Microbiology, 147, pp. 2881-2883.

22. Anawar, H.M., Freitas, M. C., Canha, N., Regina, I.S. 2011. Arsenic, Antimony, and Other Trace Element Contamination in a Mine Tailings Affected Area and Uptake by Tolerant Plant Species, Environmental Geochemistry and Health, 33, pp. 353-362.

Image Courtesies (Retrieved from)

23. http://www.mediterraneangardensociety.org/42-lavenders.html

24. https://en.wikipedia.org/wiki/Cistus ladanifer

25. https://en.wikipedia.org/wiki/Carlina_corymbosa

26. https://en.wikipedia.org/wiki/Echium_plantagineum

27. http://waste.ideal.es/rumexinduratus.htm 